\title{
Influence of Relational Psychological Contract and Affective Commitment in the Intentions of Employee to Share Tacit Knowledge
}

\author{
Petra Salazar-Fierro' ${ }^{1}$, Josefa Melgar Bayardo² \\ ${ }^{1}$ Administrative Sciences Department, Universidad Autónoma de Ciudad Juárez, Ciudad Juárez, México \\ ${ }^{2}$ Business Management Program, Administrative Sciences Department, Universidad Autónoma de Ciudad \\ Juarez, Ciudad Juárez, México \\ Email: pesalaza@uacj.mx, psalaza@hotmail.com, imelgar@uacj.mx
}

Received 19 June 2015; accepted 13 July 2015; published 16 July 2015

Copyright (C) 2015 by authors and Scientific Research Publishing Inc.

This work is licensed under the Creative Commons Attribution International License (CC BY). http://creativecommons.org/licenses/by/4.0/

(c) (i) Open Access

\begin{abstract}
Organizational knowledge represents an organized group of data and information created and maintained by individuals and business through regulations and procedures [1]. It is essentially related to human action and it is part of the company's intangible assets [2]. This continuous and complex interaction works as a reciprocal process based on a psychological contract full of reciprocal expectations which stipulate the terms of trade and engagement between people and organizations. On one hand, organizations offer rewards, while on the other hand, employee provides his contribution, conceptualized as partners willing to invest their resources as they reach their objectives and obtain mutual benefits. When tacit knowledge is shared, it allows the creation ideas that contribute to innovation, the increases of firm value and the development of sustainable competitive advantages among others advantages. This paper is based on a comprehensive literature review, by analyzing scientific papers, whose purpose is to examine the influence of relational psychological contract and affective commitment in the intentions of employee to share tacit knowledge, as factors for the transfer to be successful.
\end{abstract}

\section{Keywords}

Psychological Contract, Affective Commitment, Tacit Knowledge Sharing 


\section{Introduction}

Accentuated technological, economic, political and social changes are global factors that require organizations to remain alert [3], and thus have the ability to adapt to the changing world that imposes new practices and required the development of people able to learn and meet new challenges to compete [4].

Therefore, a central theme in the administration is precisely the difference in knowledge between organizations; that from this condition seeks to explain why some firms obtain better performance and achieve better results than its competitors [5].

When knowledge is shared, it has the possibility to improve the performance of the organization; also, by implementing strategies that encourage their employees to share the acquired knowledge, it contributes to making organizational decisions that aim to increase the competitive advantage of the firm. This continuous and complex interaction works as a reciprocal process based on a psychological contract full of reciprocal expectations that stipulate the exchange relations between people and organizations [6]. On the one hand, organizations offer rewards, while on the other hand, employee provides his contribution [7], conceptualized as partners willing to invest their resources as they reach their objectives and obtain mutual benefits [8].

There is empirical evidence that both affective commitments as the psychological contract are important predictors in the transfer of knowledge [9], but it has not shown a possible relationship with the intentions of the employee to share tacit knowledge.

This paper is based on a comprehensive literature review as a first approach in the development of this research, by analyzing scientific papers, whose purpose is to examine the influence of relational psychological contract and affective commitment in the intentions of employee to share tacit knowledge, as well as their organizational transfer. Therefore, we still do not have a method and results from an instrument.

Therefore, to develop this research some questions will be formulated to which it is intended to answer, which they are: 1) Is it positively and significantly related relational psychological contract with the intentions of the employee to share tacit knowledge? 2) Is it positively and significantly related organizational affective commitment with the intentions of the employee to share tacit knowledge? 3) Is it positively and significantly associated the intention of the employee to share tacit knowledge with the transfer?

With this research, it will advance academic knowledge and contribute in improving organizational practice, and that based on the results will be delimited if the relational psychological contract and affective commitment play an important role in the intentions of the employee to share tacit knowledge with colleagues and the transfer can be successful. In the event that the influence between these variables is confirmed, it is expected to support the knowledge generated in the design of strategies that encourage employees to share the tacit knowledge within the organization, and assist in the management processes involved welfare and employee engagement.

\section{Knowledge}

Over time, there have been proposed various definitions of knowledge, without reaching any consensus on the issue because of its complexity, which will depend largely on its importance, the kind of knowledge we want to address and how it is acquired and used to define it. Some authors defined as "a dynamic human process of justifying personal belief in search of the truth" [10]. Also Mehrabani \& Maziar (2012) [1], argue that it is a set of data and information organized that people and organizations create and maintain through rules and procedures. Meanwhile Davali \& Esmmaeil (2012) [2], mention that it is a resource essentially constituted human action that is part of the intangible assets of the organization and the value represented is difficult to keep. Therefore, the organizational knowledge should be understood as a socially constructed product and grounded on the human resources organization since people are the only source and the means to create and transmit tacit knowledge [11].

The contributions made by Nonaka \& Takeuchi (1999) [10], on the creation of organizational knowledge, focus on that knowledge is created by human interactions between individuals with different types and content knowledge and that this process can be carried out it is necessary to distinguish two dimensions: an epistemological and ontological. The epistemological dimension is the nature of knowledge, where the distinction between tacit and explicit knowledge becomes and the ontological dimension focuses on the levels where knowledge is created, which can be individual, group, organizational and inter-organizational where the interaction of tacit and explicit knowledge rises from a lower level to a higher one. This interaction between the two types of knowledge is given through a social process between individuals, where tacit knowledge and explicit knowledge expand both quantity and quality. The result of this enlargement are four ways of knowledge conversion are: so- 
cialization (tacit to tacit); externalization (from tacit to explicit); combination (from explicit to explicit); and internationalization (explicit to tacit).

Socialization, enables sharing tacit knowledge through face to face interaction between individuals through experiences. The externalization is achieved by transforming knowledge into explicit using metaphors, concepts, or models. The combination includes the exchange of knowledge of individuals through various forms of explicit knowledge, such as meetings or telephone conversations, and internalization is accomplished through the implementation of the acquired knowledge, that is its to say by action [10]. The interaction between the conversions of knowledge is given by an exponential and dynamic process that allows the expansion of knowledge creation. This organizational knowledge is called knowledge spiral (Figure 1), which may begin in any way, but usually begins from socialization [12].

Currently, companies widely use knowledge management for multiple benefits associated with them and although knowledge management, as happens with the knowledge there is no single definition or accepted, this process can refer to different activities within organizational and definitions can be directed in different directions. According to Tarí \& García (2012) [13], knowledge management is a methodological process whose purpose is to develop and exploit the acquired knowledge to improve strategic decision-making and competitiveness of the organization. Ewest (2010) [14], mentions that a range of integrated activities by which the organization obtains the right knowledge, the right people and in time and right place. Meanwhile Prieto et al., (2010) [15], defines knowledge management as a process from which it seeks to achieve organizational objectives to maintain and improve organizational performance based on experience and the knowledge conceived.

There are several areas that have been concerned about the study of knowledge, such as philosophy, sociology, psychology and social sciences branch among others. However in the organizational field it has taken great interest in this intangible asset for the many benefits it brings not only in their production processes, but it is the key leading organizations for innovation and the creation of competitive advantages [11].

Depending on the degree of structuring and coding, there are two types of knowledge that are explicit knowledge and tacit knowledge [16]. Explicit knowledge is easily encoded and stored, is expressed and communicated in written documents such as reports or manuals [17], it is public and transfer is cheaper [11]. This encoding includes the set of laws, principles and theories explaining systemized organizational reality [18]. Explicit knowledge is a public good, is the "knowledge about". Nonaka \& Takeuchi (1999) [10], argue that explicit knowledge is only the peak of the iceberg because it is visible, consisting of past events; it is, "there and then" and is created sequentially.

On the other hand, tacit knowledge is not easily encoded or articulated because it is embedded in the individual's brain and is deeply connected with the action and the commitment of the people [11]. It is rooted in the action and experience of the subject and wrapped in a particular context which makes it difficult to transform to the explicit form [19]. It is difficult to observe and transmit; it is unique, rare and irreplaceable [20]. Meanwhile, Nonaka \& Takeuchi (1999) [10], they mention that tacit knowledge is made up cognitive and technical elements. The cognitive elements focus on schemes, paradigms, mental models, pictures or figurations that the subject is forming in his mind about the perception of reality. The technical elements includes non-formal and difficult

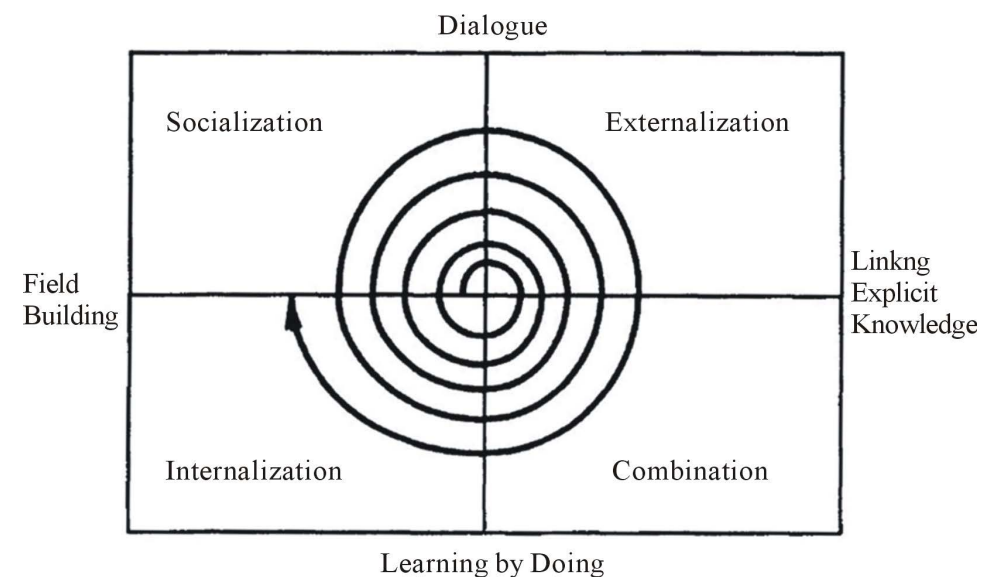

Figure 1. Knowledge spiral. Source: Nonaka \& Takeuchi (1999) [10]. 
skills to explain, associated with the term "know how" to describe the ability to perform a job or solve a problem, based on experience, values and feelings of the individual. Tacit knowledge lies in the subjectivity of the individual, where intuition, ideas and hunches are part of it; it is the "here and now" and is created simultaneously.

Polanyi, quoted by Reychav \& Weisbert (2009) [21], was one of the first to distinguish the explicit knowledge from tacit knowledge. He defined tacit knowledge as personal, specific and subjective, based on the experience itself, values and feelings of the individual to do something or solve a problem. Tacit knowledge is associated with terms such as "skill", "know-how", "working knowledge" and "expertise", concepts used to describe the knowledge and ability to perform a job [20]. However tacit knowledge cannot be studied without considering the explicit part of the knowledge base because they are mutually constituted [22]. Both are part of the organizational activities and thus explicit knowledge and tacit knowledge are interrelated [23]. Nonaka, Umemoto \& Senoo (1996) [12], claim that they are two complementary entities that interact in the human creativity both individual and in groups and both are part of the organizational activities. To identify the conceptual differences between the two types of knowledge (Table 1), some characteristics are displayed.

\section{Theorical Foundation}

The Planned Behavior Theory [24], explains the relationship between behavioral intention and actual behavior of individuals to take action. It is influenced mainly by two factors which are the attitudes of individuals directed to an object or group and a subjective standard that relates to the individual's perception about people who consider important, responding to a particular behavior [21]. Also in the field of knowledge management, the model of the Theory of Planned Behavior is used to analyze the intentions of the employee to share tacit knowledge [25]. Moreover, the Theory of Reasoned Action [26], assumes that people react to certain behavior when they are motivated and perceive more benefits, thereby increasing their intent to participate [17].

\section{Tacit Knowledge Sharing}

Organizational knowledge is integrated with both the skills of people working in a firm as to the principles of the organization through which are structured and coordinated relations between individuals and groups [11]. This intangible asset is in the rules, procedures, strategies and technologies and is the result of interactions of the persons acting on behalf of the organization [5]. It is linked to social relations and transfer typically occurs through direct contact because it demands intense interaction between members of the organization [18].

Nonaka \& Takeuchi (1999) [10], state that once tacit knowledge has been shared, should be expanded both horizontally and vertically in the organization to generate a new cycle of knowledge creation and the organization must provide the conditions and the tools that facilitate its expansion.

When tacit knowledge is transferred, changes occur in the practices, policies, and behavior seen as activities that add value to the organization [11]. For tacit knowledge transfer takes place requires the participation of both the employee and the organization. By the employee of its intention to share it is based on the will to do and the expectation of reciprocity by the recipient. Regarding the organization is required to be sensitive and show interest in this intangible asset that involves the recognition, appreciation and value of knowledge to be shared [23].

For the transfer of tacit knowledge to be successful, it was found that there are certain factors that

Table 1. Conceptual differences of knowledge.

\begin{tabular}{|c|c|}
\hline Tacit knowledge & Explicit knowledge \\
\hline It is not taught, it is learned by experience. & It can easily teach. \\
\hline It is not articulated, difficult to express in words. & It is articulated, it can be modified. \\
\hline Complex, difficult to transfer. & It is simple, easy to share. \\
\hline It is not observable: It is stored in the minds of people. & Observable in use: It is in databases, documents and systems. \\
\hline It is personal. & It is public. \\
\hline It is expensive, difficult to transfer. & It is cheaper transfer. \\
\hline
\end{tabular}

Source: Máynez \& Cavazos (2011) [11]. 
influence both positively and negatively during this process. Among the factors that influence positively is the motivation of the subject, where it is mentioned that the transfer improvement through extrinsic motivation, showing that people do because they feel committed to the organization and not for reasons to get monetary rewards [27]. It also indicates that the perception of support, trust, reward structures, differences in organizational status, leadership and social networks are closely related to the transfer of tacit knowledge [28]. Academics like Joaia \& Lemus (2010) [16], note that the idiosyncratic factors, knowledge management strategies adopted by the organization and structure are important elements to consider for the successful transfer of tacit knowledge intra-organizational. Meanwhile, Máynez, Cavazos \& Nuño de la Parra (2012) [5], state that the absorptive capacity and organizational culture also contribute to such transfer. However social relationships are probably the most important factors that facilitate the transfer of tacit knowledge among employees within an organization [19]. By contrast, the organizational culture of the company [28], the fear of losing potential benefits and the lack of mechanisms appropriate rewards are the main reasons why a person may refuse to share tacit knowledge with coworkers [19].

Most studies found agree that tacit knowledge is the primordial essence of organizations, and shared it contributes operational and financial results [29] and enables the perception of ideas that stimulate creativity resulting in a direct relationship to innovation and economic growth [30]. Also, there is empirical evidence of research conducted from different approaches, as the academics Martin, Martin, \& Trevilla (2009) [27]; Visvalingam \& Manjit Singh, (2011) [28]; they have given various factors of conceptual, organizational, personal or technological, and various combinations of these and carried out in companies from various twists, proportions and in different populations. Work carried out in various countries have addressed the tacit knowledge; [17] [19] were also found, to name a few, where mainly used the measuring instrument developed by Bock, Zmud, Kim, \& Lee (2005) [31], which evaluates the subject's behavioral intention to share tacit knowledge, in five-point Likert scale.

\section{Intention to Sharing Tacit Knowledge}

Knowledge represents a group of organized data and information that individuals and organizations create and maintain through rules and procedures [1]. It is essentially related to human action, is part of the intangible assets of the company and is a value hard to maintain [2]. However despite the various practices used by organizations it has not been easy to convince employees to share the acquired knowledge, since it is owned by the individuals who make and they are the sole possessors of control and decision of share it [32].

Sharing knowledge is a major challenge for organizations and has forced them to pay more attention to the implementation of strategies to capture that knowledge for the many advantages which represents them, because when that knowledge is not shared, run the risk of losing it, especially when the employee leaves the workplace, causing costs to the company [25].

Sharing knowledge means sharing among employees is the act of making available knowledge to others and contributes to the creation of a knowledge database of the organization [21]. Nonaka \& Takeuchi (1999) [10], suggest that tacit knowledge should be transferred and shared between members of an organization and convert it to numbers or words that everyone understands.

By sharing tacit knowledge, ideas emerge that contribute to innovation [33], increases the production of the organization, skills and competencies are created, the value of the firm increases and develop sustainable competitive advantages [23]. Also has the potential to improve the performance of the organization; as well as through the implementation of strategies that encourage their employees to share the acquired knowledge is contributes in making organizational decisions that aim to increase the competitive advantage of the firm [11]. Most studies found agree that tacit knowledge is the primordial essence of organizations, contributes to the benefit of both operating results and financial [29] and enables the perception of ideas that stimulate creativity resulting in direct relation to innovation and economic growth [30].

Although tacit knowledge is considered a personal asset where the individual has complete control and determination to share [32], other studies have suggested the advantages of share at the group level [30]. At group level, on the one hand, organizations maintain their structure and coherence [29] and the other remains a high level of group and organizational productivity. Individually, when the employee share tacit knowledge with others coworkers, organizational performance as well as the absorption capacity and innovation is enhanced [17].

Moreover, studies indicate that employees who share the tacit knowledge do not seek a monetary rewards for doing so, those who do are people with better performance in the organization, showing an increased interest in 
participation and interaction with coworkers and their intentions to leave the company are limited [21].

There is empirical evidence that the intentions to share knowledge can be induced by the effect of confidence and internal control, while external control positively moderates the process and the individual's behavior and shared values are negatively related to the intentions of the subject to share tacit knowledge [19]. Factors like empathy and affection to the organization or to certain people may be elements that predispose the intention to share knowledge [5].

Nonaka \& Takeuchi (1999) [10], state that the interaction of individuals to that tacit knowledge can be shared is necessary face to face with the path of dialogue to share their experiences, which helps speed up the pace for the creation of organizational knowledge. However, Wamitu (2015) [34], mentions that in order to understand this condition is necessary to understand why people choose to share their knowledge in some cases and not in others. Yong et al. (2013) [17], says that the intention or willingness of an individual to share knowledge, is viewed as the extent to which the employee thinks participate in an event and reflects personal choices of the individual to act in a way determined, driven by an emotional reaction which combines both intellectual and personality characteristics.

\section{Psychological Contract}

A psychological contract assesses the interrelations among rights, responsibilities, promises and obligations between stakeholders [35]. It promotes the reduction of insecurity in employment since it is focused on job security, continuity, loyalty and justice where new forms of flexible contracts arise. There is a clear focus on the employment relationship between employee employer whereby the employee expects that their psychological contract is different from traditional contracts [36]. It provides the opportunity to explore the processes and content of employment [37]. It influences the behavior of both parties, it is more contractual, expectations have a more generic meaning [7], and it is an important element in any employment relationship [38].

In the literature there are many definitions to refer to the psychological contract. According to Rousseau (1989) [39], a psychological contract is an individual belief, regardless of the terms and conditions. Fantinato \& Casado (2011) [7], says it is a reciprocal exchange between the focal person and the other party. Other researchers define it as the reciprocal expectation of the individual and the organization representing the ideas about organization employee relationship [40], where the individualization of the relationship is captured reflecting individual needs and its implicit expectations on the employer [41]. For their part another academics [9], mentioned that it is a tacit agreement between the individual and the organization in which both sides hope that the agreements reached are respected and carried out fully. It is an unwritten agreement, much more than a formal employment contract that sets out what the administration hopes the employee and vice versa [42].

The works that most influenced the academic community regarding the concept of psychological contract was to Levinson and his colleagues in 1963 and Schein in 1965, who left aside the central idea that such contracts are mutual expectations between individuals and organizations and they are strongly rooted in the perception of change in the employment [7]. This legacy was the pattern to express the concept by various authors and even without a written contract between the employee and the organization, both are linked to a psychological contract consists of responsibilities and social norms [35].

There are three main features of the theory of psychological contract that continue to capture the interest of researchers. First, it is depicted as a general framework for understanding the employment relationship and its evolution over time. Second, the view provided in individual reactions to organizational change and third the interest of helping employees understand how to react when the psychological contract breach [43]. Other features found making up the psychological contract are supported by the hierarchical organizational culture [6], change processes [44] and the resemblance to a traditional employment contract as a mental model of employees attitudes [36].

On the other hand it provides a comprehensive model that focuses on two factors that affect organizational change and generational differences among employees [36]. These effects on the one hand affect the organizational commitment through compensation practices and knowledge sharing, intention of leave, performance and organizational citizenship behaviors [9] and on the other, the individual characteristics of the subject's personality and expectations about the career change over time [45]. Also the psychological contract is perceived differently between employees and employers in labor relation, which some authors call inconsistency in perceptions [41] [46]. 
Among the variables that have been linked more the psychological contract include affective commitment [43] [47], organizational culture [6], burnout and organizational citizenship behaviors [45], trust and organizational commitment [48], job satisfaction [36] [49] [50], strategic compensation practices and knowledge sharing [9], perception organizational support [51], intended to leave [35] [52], the downsizing [53], organizational commitment and job retention [54] among others.

\subsection{Breach of the Psychological Contract}

Over time the psychological contract takes the form of a scheme or mental model, which makes relatively stable and lasting [44]. This scheme guides the perception of people about how to interpret the information received and how to react to the environment around them [41].

When one party perceives that the other has failed to fulfill one of its obligations [52], that's cognitively evaluates the breach of obligations tacitly agreed in the employment relationship with the organization [50], then a breach of the psychological contract occurs.

The breach of the psychological contract is a cognitive or perceptual employee that promise agreed with your employer was not fulfilled. This condition forces him to evaluate the employment aspect, which may lead him to react to such a disruption by revenge, depression or sadness [7]. This breach causes damage and directly and indirectly affects both individual and organizational levels [43]. On a personal level, it affects the most general beliefs of the person about their confidence in their employer and perceived justice in the employment relationship justice [45] responding employee strongly to limit its own contribution to the organization rather than restore balance, experiencing the lowest level of commitment to the organization [55] and triggering attitudes and negative behaviors [56]. In a study about the perception of the relationship between age and the breakdown of the psychological contract by the academics Alcover \& Martínez-Inigo (2012) [51], they mentioned that breach of psychological contract perceived by workers above 50 age increases compared to individuals younger age. Moreover at the organizational level, the results are decrease in satisfaction and labor welfare, leave intention [35], levels of confidence, especially when the levels of trust between leaders and employees was high [49], low organizational citizenship, increase in volunteer labor rotation and bad or poor relationships [7] are just some factors affecting directly the breach of psychological contract thereby causing a major impact on the performance of the organization [37].

Likewise the breach of the psychological contract can occur due to several factors. For organizations, competi-tion and the constant economic changes can pose situations in which the fulfilments of the promises made to its employees are difficult or unprofitable. For employees, the factors found that directly affect the breach of the psychological contract [45] are organizational citizenship behaviors, organizational commitment, trust as well as difference of perception or inconsistencies [57].

There is empirical evidence that the breach of the psychological contract is positively related with the cynical attitudes toward change and burnout, has a significant effect on organizational trust and this in turn manifests on affective dimensions and regulations organizational commitment and loyalty [45]. It has a negative effect with organizational identification, satisfaction and organizational citizenship behaviors and a predictive effect on both attitudinal and behavioral results of the members of the organization [52] [54].

\subsection{Transactional Psychological Contract}

Transactional contract is determined by a certain period of time, usually short [6], where the employee will remain under well-defined and specific conditions of exchange [38]. There is very little participation among involved parties and is characterized by being purely materialistic where employees only work to achieve an economic reward and therefore linked to negative results particularly with the organizational commitment [47].

\subsection{Relational Psychological Contract}

Relational contract includes loyalty, trust and mutual stability, employees are more willing to work, help to coworkers and support organizational changes [38]. It is based on the mutual agreement of both monetary as emotional elements exchanges [6] where the rewards are contingent upon indefinitely derived from membership and participation in the organization [7]. It focuses on a long-term lasting relationship aimed at the development of the employee [47]. It is positively and significantly related to the organizational commitment [6]. 
There is empirical evidence that the relational psychological contract is positively related with the culture of clan, acts as mediator between organizational culture and organizational commitment [54] among others and its breach is related to intention to leave [58].

\section{Commitment}

Commitment is a force that unites the individual to an ongoing action which can be a process [59] objectives and values [4] or willingness to exert work effort on behalf of the institution [60] where every conflict party are willing to give up something and keep a stay in harmony.

Organizational commitment is the preparation of the employee to work hard on behalf of the organization, accepting their ideas [61], goals, standards, ethics and values [62]. It is a mental and emotional dependence where the employee is identified and enjoy belonging to the organization [60]. However the most popular definition of organizational behavior corresponds to Allen and Meyer [63], who conceptualized it as a psychological state that constitute the relationship between a person and organization.

Over time, researchers have described the commitment as multidimensional reflecting the varied reasons to keep a relationship and can be categorized into normative commitment, continuance commitment and affective commitment [64].

\subsection{Normative Commitment}

Normative commitment is the moral duty of the employee to remain in the organization because it should and is obliged to do so [4] [65] [66]. It is the individual psychological association with the organization through the internalization of his vision, goals, principles, values and missions [62] displaying individual ethical conduct based on his belief in doing good [67] [68].

Employees with high levels of normative commitment think that they have to remain in the organization because it is indeed right [62]. When employees receive training they feel compelled to contribute for it and those feelings of loyalty may reflect in the socialization processes [61]. It is positively related with organizational citizenship behavior [62] and affective behavior and it presents major conceptual problems [59].

\subsection{Continuance Commitment}

Continuance commitment is the need to remain in the organization based on awareness of the employee with respect to the investment in time and effort to lose in case of leaving the organization and seek other employment [65]. This investment is in the perception of the associated costs either economics or notto leave the organization and the lack of alternative employment [4] [68] does not allow him another option than remain in the organization for fear of losing their benefits, pay or unemployment [61].

The continuance commitment is associated with different schemes of motivation that affects differently in individual behavior [65]. It is a precursor to leave the organization and is not related to organizational citizenship behavior [59].

\subsection{Affective Commitment}

Affective commitment is a strong belief and dedication to the goals and organizational values [4] [67], with which the worker is identified generating a sense of pride to be part of it [65]. It includes psychological phenomena and emotional ties and a sense of unity and desire to achieve the goals for the organization [66]. It is an association where the parties involved maintain a relationship and their desire to preserve it [64]. Occurs at the individual level [69], it is affective [59] and sense of belonging that identified the employee as an active member in the organization [61].

Affective commitment is the most decisive indicator of organizational change and integration to work [69]. Employees with a high level of affective commitment are more motivated and have a strong desire for contribution and performance to the organization [70]. They are emotionally committed, willing to invest time and energy to achieve the organizational goals [71]. This identification occurs when the assets of the employee are consistent with the organization's values and assumes its objectives [72]. Also is a strong intrinsic motivation in the individual [72], so it is related to attitudes and positive behaviors and labor welfare [66] when the employee perceives that the organization values their contributions and cares for his welfare, needs for affiliation, mem- 
bership approval, emotional support and esteem will be fulfilled, assuming the harmony of the organization as his own and feels emotionally identified with it [71]. Also it has been linked to personal characteristics of the individual, organizational structures and work experiences [9] including payment, supervision, clarity in the description of work and range of skills [61]. It is a robust predictor of organizational desirable outcomes such as employee retention [51], leave intention, labor absenteeism, justice, organizational climate and culture [66] and strongly associated with withdrawal cognitions, job performance and organizational citizenship behavior [73]. Researches indicate that both the affective organizational commitment and psychological contract are positively related to knowledge sharing [9]. However there have also been identified background that affect affective commitment of people like affection and expectations of membership in the organization that allow the individual to form stable commitments [66].

In a research on affective commitment levels in different cultures by Meyer et al., (2012) [74], they founded that there is great variation between cultural values and practices of subjects, information that is of interest to multinational organizations as well as enterprises that employ persons from different cultural backgrounds. In another study about relationships between career motivation, affective commitment and job satisfaction accomplished by Alniacik, Alniacik, Akcin, \& Serhat (2012) [70], they found that career motivation differs in terms of gender as female perception is higher compared with male and as for the individual characteristics of age, income or stay no change was observed.

\section{Conclusions}

Organizational knowledge is an intangible asset that guides the direction of the organization. It is in the rules, procedures, strategies and technologies, and is the result of interactions of individuals acting on behalf of the organization and so it can be leveraged. It is necessary to understand the behavior of their employees, motivate them and encourage them to share the knowledge gained with other coworkers. This process involves mutual expectations among stakeholders, where on one hand the organization offers rewards to their workers to do their best effort and on the other hand the worker agrees with the objectives of the organization to share tacit knowledge because sharing that knowledge helps the company in the development of ideas that contribute to innovation and especially the development of sustainable competitive advantages.

This document is limited because firstly, it is a first approach to literature review on the subject under study. In Mexico research conducted on the subject, they have been isolated and limited, so exploration is necessary to know the behavior of both employees and employers in this region, where cultural factors and context may be different from other countries, so it is important to make comparisons with other populations and productive sectors to learn the results and analyze their behavior.

In the second place, to give continuity to the research, hypotheses will be tested and research questions will be answered to obtain a valid result. It is expected that the knowledge generated supports in designing strategies that encourage employees to share the tacit knowledge within the organization, and assist in the management processes related to the wellness and employee commitment.

\section{References}

[1] Mehrabani, S. and Maziar, S. (2012) Knowledge Management and Innovation Capacity. Journal of Management Research, 4.

[2] Davali, M.M. and Esmmaeil, M. (2012) Investigating Organizational Knowledge Management in Control and Supervision (General Inspection Organization). Interdisciplinary Journal of Contemporary Research Business, 4, 1077-1090.

[3] Chiavenato, I. (2009) Gestión del talento humano. México D.F.

[4] Robbins, S.P. and Judge, T.A. (2009) Comportamiento Organizacional. Decimotercera Edition, Pearson Prentice Hall, México D.F.

[5] Máynez, A., Cavazos, J. and Nuño de la Parra, J.P. (2012) La influencia de la cultura organizacional y la capacidad de absorción sobre la transferencia de conocimiento tácito intra-organizacional. Estudios Gerenciales, 28, 191-211.

[6] Richard, O.C., et al. (2009) Antecedents and Consequences of Psychological Contracts: Does Organizational Culture Really Matter? Journal of Business Research, 62, 818-825. http://dx.doi.org/10.1016/j.jbusres.2008.04.001

[7] Fantinato, L. and Casado, T. (2011) Contratos psicológicos: Uma revisão da literatura. Revista de Administración, 47, 571-580. 
[8] Chiavenato, I. (2007) Administración de recursos humanos. McGraw-Hill/Interamericana Editores, S.A. de C.V., México D.F.

[9] Anvari, R., et al. (2014) Mediating Effects of Affective Organizational Commitment and Psychological Contract in the Relationship between Strategic Compensation Practice and Knowledge Sharing. Procedia-Social and Behavioral Sciences, 129, 111-118. http://dx.doi.org/10.1016/j.sbspro.2014.03.655

[10] Nonaka, I. and Takeuchi, H. (1999) La organización creadora del conocimiento. Oxford University Press, México D.F.

[11] Máynez Guaderrama, A.I. and Cavazos Arroyo, J. (2011) Conocimiento tácito: Su transferencia dentro de la organización, como fuente de ventaja competitiva sostenible. Tomado de Administracion y Organizaciones, 13, 9-26.

[12] Nonaka, I., Umemoto, K. and Senoo, D. (1996) From Information Processing to Knowledge Creation: A Paradigm Shift in Business Management. Technology in Society, 18, 203-218. http://dx.doi.org/10.1016/0160-791x(96)00001-2

[13] Tarí, J. and García, M. (2012) Puede la gestión del conocimiento influir en los resultados empresariales? Cuadernos de Gestión, 13, 151-176.

[14] Ewest, T. (2010) Gestión del conocimiento y eficacia organizacional: Considerando aplicaciones para liderazgo. Revista de Negocios e Investigación Económica, 8.

[15] Prieto, I.M., Pérez, M.P. and Martín, C. (2010) Gestión del conocimiento a través de prácticas de recursos humanos: Examinación empírica en la industria automotriz española. The International Journal of Human Resource Management, 21, 2452-2467.

[16] Joaia, L.A. and Lemus, B. (2010) Relevant Factors for Tacit Knowledge Transfer within Organisations. Journal of Knowledge Management, 14, 410-427. http://dx.doi.org/10.1108/13673271011050139

[17] Hau, Y.S., Kim, B., Lee, H. and Kim, Y.-G. (2013) The Effects of Individual Motivations and Social Capital on Employees' Tacit and Explicit Knowledge Sharing Intentions. International Journal of Information Management, 33, 356366. http://dx.doi.org/10.1016/j.ijinfomgt.2012.10.009

[18] Reychav, I. and Weisberg, J. (2010) Bridging Intention and Behavior of Knowledge Sharing. Journal of Knowledge Management, 14, 285-300. http://dx.doi.org/10.1108/13673271011032418

[19] Yang, S.-C. and Farn, C.-K. (2009) Social Capital, Behavioural Control, and Tacit Knowledge Sharing-A Multi-Informant Design. International Journal of Information Management, 29, 210-218. http://dx.doi.org/10.1016/j.ijinfomgt.2008.09.002

[20] Oğuz, F. and Şengün, A.E. (2011) Mystery of the Unknown: Revisiting Tacit Knowledge in the Organization Literature. Journal of Knowledge Management, 5, 445-461. http://dx.doi.org/10.1108/13673271111137420

[21] Reychav, I. and Weisberg, J. (2009) Good for Workers, Good for Companies: How Knowledge Sharing Benefits Individual Employees. Knowledge and Process Management, 16, 186-197. http://dx.doi.org/10.1002/kpm.335

[22] Nonaka, I. and von Krogh, G. (2009) Perspective-Tacit Knowledge and Knowledge Conversion: Controversy and Advancement in Organizational Knowledge Creation Theory. Organization Science, 20, 635-652. http://dx.doi.org/10.1287/orsc.1080.0412

[23] Máynez, A., et al. (2012) Identificación de factores comunes estudiados, relacionados con la transferencia de conocimiento tácito dentro de las organizaciones. Revista Internacional Administración y Finanzas, 5, 103-117.

[24] Ajzen, I. (1991) The Theory of Planned Behavior. Organizational Behavior and Human Decision Processes, 50, 179211. http://dx.doi.org/10.1016/0749-5978(91)90020-t

[25] Olatokun, W. and Nwafor, C.I. (2012) The Effect of Extrinsic and Intrinsic Motivation on Knowledge Sharing Intentions of Civil Servants in Eboni State, Nigeria. Information Development, 28, 216-234.

[26] Ajzen, I. and Fishbein, M. (1991) The Influence of Attitudes on Behavior. In: Albarracin, D., Johnson, B.T. and Zana, M.P., Eds., The Handbook of Attitudes, 32.

[27] Cruz, N.M., Pérez, V.M. and Cantero, C.T. (2009) The Influence of Employee Motivation on Knowledge Transfer. Journal of Knowledge Management, 13, 478-490. http://dx.doi.org/10.1108/13673270910997132

[28] Suppiah, V. and Sandhu, M.S. (2011) Organisational Culture’s Influence on Tacit Knowledge-Sharing Behaviour. Journal of Knowledge Management, 15, 462-477. http://dx.doi.org/10.1108/13673271111137439

[29] Venkitachalam, K. and Busch, P. (2012) Tacit Knowledge: Review and Possible Research Directions. Journal of Knowledge Management, 16, 357-372. http://dx.doi.org/10.1108/13673271211218915

[30] Subashini, R. (2010) Tacit Knowledge-The Ultimate Essence of an Organization. Advances in Management, 3, 36.

[31] Bock, G.-W., et al. (2005) Behavioral Intention Formation in Knowledge Sharing: Examining the Roles of Extrinsic Motivators, Social-Psychological Forces, and Organizational Climate. MIS Quarterly, 29, 87-111.

[32] Casimir, G., Lee, K. and Mark, L. (2012) Knowledge Sharing: Influences of Trust, Commitment and Cost. Journal of Knowledge Management, 16, 740-753. http://dx.doi.org/10.1108/13673271211262781 
[33] Matzler, K. and Mueller, J. (2011) Antecedents of Knowledge Sharing Examining the Influence of Learning and Performance Orientation. Journal of Economic Psychology, 32, 317-329. http://dx.doi.org/10.1016/j.joep.2010.12.006

[34] Wamitu, S.N. (2014) Tacit Knowledge Sharing in Public Sector Departments in Kenya. Open Journal of Business and Management, 3, 109-118. http://dx.doi.org/10.4236/ojbm.2015.31011

[35] Aykan, E. (2014) Effects of Perceived Psychological Contract Breach on Turnover Intention: Intermediary Role of Loneliness Perception of Employees. Procedia-Social and Behavioral Sciences, 150, 413-419. http://dx.doi.org/10.1016/j.sbspro.2014.09.040

[36] van der Smissen, S., Schalk, R. and Freese, C. (2013) Contemporary Psychological Contracts: How Both Employer and Employee Are Changing the Employment Relationship. Management Revue. Socio-Economic Studies, 24, 309327.

[37] Jafri, H. (2014) Influence of Personality on Perception of Psychological Contract Breach. Psychological Thought, 7, 168-178. http://dx.doi.org/10.5964/psyct.v7i2.113

[38] Lee, H.-W. and Liu, C.-H. (2009) The Relationship among Achievement Motivation, Psychological Contract and Work Attitudes. Social Behavior and Personality, 37, 321-328. http://dx.doi.org/10.2224/sbp.2009.37.3.321

[39] Rousseau, D.M. (1989) Psychological and Implied Contracts in Organizations. Employee Responsibilities and Rights Journal, 2, 121-139. http://dx.doi.org/10.1007/BF01384942

[40] Freese, C. and Schalk, R. (2008) How to Measure the Psychological Contract? A Critical Criteria-Based Review of Measures. South African Journal of Psychology, 38, 269-286. http://dx.doi.org/10.1177/008124630803800202

[41] Randmann, L. (2013) Managers on the Both Sides of the Psychological Contract. Journal of Management and Change, 30-31, 124-144.

[42] Agarwal, U.A. and Bhargava, S. (2013) Effects of Psychological Contract Breach on Organizational Outcomes: Moderating Role of Tenure and Educational Levels. Vikalpa: The Journal for Decision Makers, 38, 13.

[43] Cassar, V. and Briner, R. (2011) The Relationship between Psychological Contract Breach and Organizational Commitment: Exchange Imbalance as a Moderator of the Mediating Role of Violation. Journal of Vocational Behavior, 78, 283-289. http://dx.doi.org/10.1016/j.jvb.2010.09.007

[44] Topa, G. and Morales, J.F. (2008) Cambio organizacional en la educación superior a distancia: La re-negociación del contrato psicológico de los empleados. Archivos Analíticos de Políticas Educativas, 16, 1-25.

[45] Topa Cantisano, G., Palací Descals, F. and Morales Domínguez, J.F. (2004) La ruptura de contrato psicológico y las respuestas del trabajador? Relaciones mediadas por la confianza organizacional? Revista de Psicología del Trabajo y de las Organizaciones, 20, 31-45.

[46] Sok, J., Blomme, R. and Tromp, D. (2013) The Use of the Psychological Contract to Explain Self-Perceived Employability. International Journal of Hospitality Management, 34, 274-284. http://dx.doi.org/10.1016/j.ijhm.2013.03.008

[47] Matthijs Bal, P., Kooij, D.T.A.M. and De Joung, S.B. (2013) How Do Developmental and Accommodative HRM Enhance Employee Engagement and Commitment? The Role of Psychological Contract and SOC Strategies. Journal of Management Studies, 50, 545-572. http://dx.doi.org/10.1111/joms.12028

[48] Palací, F. and Morales, J. (2004) La ruptura del contrato psicologico y las respuestas del trabajador. Relaciones medidas por la confianza organizacional. Psicología del Trabajo y de las organizaciones, 20, 31-45.

[49] Tsui, P.-L., Lin, Y.-S. and Yu, T.-H. (2013) The Influence of Psychological Contract and Organizational Commitment on Hospitality Employee Performance. Social Behavior and Personality, 41, 443-452. http://dx.doi.org/10.2224/sbp.2013.41.3.443

[50] Wang, Y.-D. and Hsieh, H.-H. (2014) Employees’ Reactions to Psychological Contract Breach: A Moderated Mediation Analysis. Journal of Vocational Behavior, 85, 57-66. http://dx.doi.org/10.1016/j.jvb.2014.04.003

[51] Alcover, C.-M., Martínez-Íñigo, D. and Chambel, M.J. (2012) Perceptions of Employment Relations and Permanence in the Organization: Mediating Effects of Affective Commitment in Relations of Psychological Contract and Intention to Quit. Psychological Reports, 110, 839-853. http://dx.doi.org/10.2466/01.07.21.PR0.110.3.839-853

[52] Lapointe, E., Vandenberghe, C. and Boudrias, J.-S. (2013) Psychological Contract Breach, Affective Commitment to Organization and Supervisor, and Newcomer Adjustment: A Three-Wave Moderated Mediation Model. Journal of Vocational Behavior, 83, 528-538. http://dx.doi.org/10.1016/j.jvb.2013.07.008

[53] Massingham, P. (2014) The Relationship between Contextual Factor, Psychological Contract and Change Outcomes. Strategic Change, 22, 157-173. http://dx.doi.org/10.1002/jsc.1930

[54] Upasna, A. and Shivganesh, B. (2013) Effects of Psychological Contract Breach on Organizational Outcomes: Moderating Role of Tenure and Education Levels. Vikalpa: The Journal for Decision Makers, 38, 13.

[55] Lapalme, M.-E., Simard, G. and Tremblay, M. (2010) The Influence of Psychological Contract Breach on Temporary Workers’ Commitment and Behaviors: A Multiple Agency Perspective. Journal of Business \& Psychology, 26, 311- 
324. http://dx.doi.org/10.1007/s10869-010-9190-5

[56] Hussain, A. (2014) The Relationship between Breach of Psychological Contract and Workplace Deviant Behavior. Journal of Organizational Behavior, 13, 25-37.

[57] Shahnawaz, M. and Goswami, K. (2011) Effect of Psychological Contract Violation on Organizational Commitment, Trust and Turnover Intention in Private and Public Sector Indian Organizations. Vision: The Journal of Business Perspective, 15, 209-217. http://dx.doi.org/10.1177/097226291101500301

[58] Ebru, A. (2014) Effects of Perceived Psychological Contract Breach on Turnover Intention: Intermediary Role of Loneliness Perception of Employees. Media Social and Behavioral Sciences, 150, 413-419.

[59] Sallan, J.M., et al. (2009) Estudio de la relación entre el compromiso organizativo y la intención de abandonar la organización: Modelo de dos componentes de compromiso de continuidad. Cuadernos de Gestión, 10, 15-28. http://dx.doi.org/10.5295/cdg.090151js

[60] Ghorbanhosseini, M. (2013) The Effect of Organizational Culture, Teamwork and Organizational Development on Organizational Commitment: The Mediating Role of Human Capital. Tehnicki Vjesnik, 20, 1019-1025.

[61] Deniz, N., Noyan, A. and Ertosun, Ö.G. (2013) The Relationship between Employee Silence and Organizational Commitment in a Private Healthcare Company. Procedia-Social and Behavioral Sciences, 99, 691-700. http://dx.doi.org/10.1016/j.sbspro.2013.10.540

[62] Sheik Mohamed, M. and Anisa, H. (2012) Relationship between Organizational Commitment and Organizational Citizenship Behavior. Journal of Organizational Behavior, 11, 7-22.

[63] Allen, N.J. and Meyer, J.P. (1996) Affective, Continuance, and Normative Commitment to the Organization: An Examination of Construct Validity. Journal of Vocational Behavior, 49, 252-276. http://dx.doi.org/10.1006/jvbe.1996.0043

[64] Lovblad, M. and Bantekas, A. (2010) What Do You Expect? The Effect of Psychological Contracts on Affective Commitment in Industrial Marketing Relationships. Journal of Relationship Marketing, 9, 161-178. http://dx.doi.org/10.1080/15332667.2010.502009

[65] Maldonado-Radillo, S.E., Guillén, A.M. and Carranza, R.E. (2011) El compromiso organizacional del personal administrativo en una universidad pública. Revista Internacional Administracion \& Finanzas, 4, 121-131.

[66] Breitsohl, H. and Ruhle, S. (2013) Residual Affective Commitment to Organizations: Concept, Causes and Consequences. Human Resource Management Review, 23, 161-173. http://dx.doi.org/10.1016/j.hrmr.2012.07.008

[67] Haque, A. and Aslam, M.S. (2014) The Influence of Emotional Exhaustion on Intention to Stay in the Organization: Mediating Role of Affective Commitment. International Journal of Management and Innovation, 6, 16-30.

[68] Kyei-Poku, I. and Miller, D. (2013) Impact of Employee Merger Satisfaction on Organizational Commitment and Turnover Intentions: A Study of a Canadian Financial Institution. International Journal of Management, 30, $205-223$.

[69] McKay, K., Kuntz, J. and Naswall, K. (2013) The Effect of Affective Commitment, Communication and Participation on Resistance to Change: The Role of Change Readiness. New Zealand Journal of Psychology, 42, 29-40.

[70] Alnıaçık, Ü., Alnıaçık, E., Akçin, K. and Erat, S. (2012) Relationships between Career Motivation, Affective Commitment and Job Satisfaction. Procedia-Social and Behavioral Sciences, 58, 355-362. http://dx.doi.org/10.1016/j.sbspro.2012.09.1011

[71] Poon, J.M. (2013) Relationships among Perceived Career Support, Affective Commitment, and Work Engagement. International Journal of Psychology, 48, 1148-1155. http://dx.doi.org/10.1080/00207594.2013.768768

[72] Rusu, R. (2013) Affective Organizational Commitment, Continuance Organizational Commitment or Normative Organizational Commitment? Revista Academiei Forţelor Terestrenr, 2, 192-197.

[73] Phipps, S.T., Prieto, L.C. and Ndinguri, E.N. (2013) Understanding the Impact of Employee Involvement on Organizational Productivity: The Moderating Role of Organizational Commitment. Journal of Organizational Culture, Communications and Conflict, 17, 107-120.

[74] Meyer, J.P., et al. (2012) Affective, Normative, and Continuance Commitment Levels across Cultures: A Meta-Analysis. Journal of Vocational Behavior, 80, 225-245. http://dx.doi.org/10.1016/j.jvb.2011.09.005 